\title{
A Brief History of the Japan Society for Cell Biology
}

\author{
Yutaka Tashiro $^{1}$ and Tohru Okigaki ${ }^{2}$ \\ ${ }^{1}$ Honorary Member of the Japan Society for Cell Biology, Higashionocho 93, Koyama, Kitaku, Kyoto 603-8162, \\ Japan and ${ }^{2}$ Director Emeritus of Shigei Medical Research Institute, Okayama 701-0202; Dean of Students and \\ Professor of Kinki Welfare University, Fukusaki 679-2217, Japan
}

\begin{abstract}
The Japan Society for Cell Biology (JSCB) was first founded in $\mathbf{1 9 5 0}$ as the Japan Society for Cellular Chemistry under the vigorous leadership of Seizo Katsunuma, in collaboration with Shigeyasu Amano and Satimaru Seno. The Society was provisionally named as above simply because cell biology had not yet been coined at that time in Japan, although in prospect and reality the Society was in fact for the purpose of pursuing cell biology. Later in 1964, the Society was properly renamed as the Japan Society for Cell Biology. After this renaming, the JSCB made great efforts to adapt itself to the rapid progress being made in cell biology. For this purpose the Society's constitution was created in 1966 and revised in 1969. According to the revised constitution, the President, Executive Committee and Councils were to be determined by ballot vote. The style of the annual meetings was gradually modified to incorporate general oral and poster presentations in addition to Symposia (1969-1974). The publication of annual periodicals in Japanese called Symposia of the Japan Society for Cellular Chemistry (19511967) and later Symposia of the Japan Society for Cell Biology (1968-1974) was replaced by a new international journal called Cell Structure and Function initiated in 1975. This reformation made it possible for the Society to participate in the Science Council of Japan in 1975 and finally in 1993 to acquire its own study section of Cell Biology with grants-in-aid from the Ministry of Education and Science, Japan. The JSCB hosted the 3rd International Congress on Cell Biology (ICCB) in 1984 and the 3rd Asian-Pacific Organization for Cell Biology (APOCB) Congress in 1998, thus contributing to the international advancement of cell biology. Now the membership of JSCB stands at approximately 1,800 and the number of presentations per meeting is 300 to 400 annually. Although a good number of interesting and important findings in cell biology have been reported from Japan, the general academic activity of the JSCB is far less than one might expect. This is simply due the fact that academic activity in the field of cell biology in Japan is divided among several other related societies such as the Japan Society for Molecular Biology and the Japan Society for Developmental Biology, among others.
\end{abstract}

In 1997 the Japan Society for Cell Biology (JSCB) celebrated its 50th anniversary at Pacifico Yokohama, Yokohama. At this meeting one of the authors, Yutaka Tashiro was asked to speak on the Society's history under the title, "The Past, Present and Future of the Japan Society for Cell Biology." This lecture was published in Japanese in Saibo Seibutsu (Vol. 9. 8-31 (1998)), the Society's newsletter. It is our great pleasure and honor to introduce here an English version of the brief history of the JSCB in the very first issue of Cell Structure and Function in the 21st century, especially emphasizing the founding and development of the Society.

\section{The Foundation of the Japan Society for Cellular Chemistry, 1950}

In 1949, Seizo Katsunuma, then President of Nayoga
University, eagerly aimed to found an epochmaking new society for cell study. A hematologist originally, he had been Professor of Internal Medicine at Nagoya University for 30 years, and was not only an outstanding physician but also a distinguished pathologist and histochemist. His major research interest was intracellular oxidation, especially in leucocytes, on which he wrote a renowned book, Intrazelluläre Oxydation un Indophenolblausynthese, published by Gustav Fischer, Jena, in 1924.

His appointment to the presidency of Nagoya University in 1949 made it difficult for him to carry on his research work steadily, and as he considered what he could do for the advancement of biomedical science in Japan, the idea flashed in his mind to organize a completely new society for cell research by a combined group of morphologists, biochemists, physiologists, chemists and physicists who were interested in the phenomenon of the cell life and were aware 


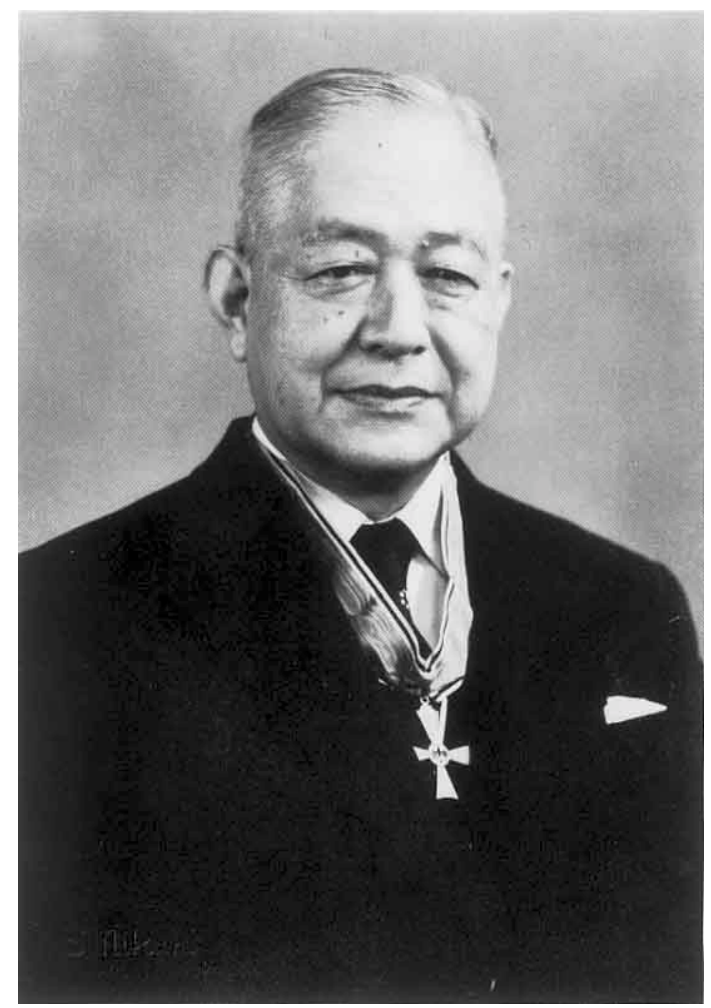

Fig. 1. Dr. Seizo Katsunuma (1886-1963), Founder of the Japan Society for Cellular Chemistry.

of the need for communication along interdisciplinary lines that existing professional societies did not provide. It is evident that Katsunuma's founding philosophy for the Society is similar to that of the American Society for Cell Biology (ASCB) which was founded in 1960.

When organizing the new Society Katsunuma consulted his intimate colleague, Shigeyasu Amano, then Associate Professor of Kyoto University, who heartily approved of his plan and recommended Satimaru Seno, Professor of Mie Medical School, to be secretary of the new Society. The authors would emphasize that historically speaking, the JSCB predated the ASCB by a decade.

The first preliminary meeting was held on January 29, 1950 in Nagoya. Katsunuma presented his idea to all the participants to establish a new Society and consulted them as to its name. In 1950 the Japanese term for cell biology, saibo seibutsugaku, had yet to be coined, hence no one at that meeting, not even its founders, had any idea of this term. As a result, Katsunuma tentatively proposed the name the Japanese Cytochemical Society, or more properly the Japan Society for Cellular Chemistry. He declared, however, that this name was not a wholly satisfactory one, and that we should not limit ourselves to histochemistry and cytochemistry, but combine numerous disciplines, technology and methodology to clarify that exceedingly complex biological phenomena of the cell.
Another significant idea that Katsunuma heartily encouraged for the new Society was free and active discussion and debates from various viewpoints by all members of the Society regardless of age or status. He preferred symposia rather than conventional oral presentations which were typical of the existing societies in Japan at that time.

In 1950, three meetings of the Society were held on January 29 and April 8 in Nagoya, and November 23-24 in Kanazawa. After the third meeting, it was decided that the meetings would be held once a year as shown in Table I.

Annual meetings of the new Society were exclusively symposia, and their proceedings were published as Symposia of the Society for Cellular Chemistry, which continued in this manner for the next 20 years (1950-1970).

Symposia topics in the first five years (1951-1955) were Development and heredity (1951), Respiratory enzymes and adaptation (1952), Surface biochemistry (1953), Nerve (1954), and Fibers and fibrous structures in the cell (1955). Usually 10 to 20 reports were presented at each symposium and discussed extensively, the symposia always attracting all the participants including young scientists.

The most exciting event in this early period was hosting of the First and Second International Symposium for Cellular Chemistry at Biwako Hotel, Otsu, on March 27-31, 1963, and October 17-21, 1966. The theme of the first one was Intracellular Membraneous Structure, and was attended by such distinguished cell biologists as H.S. Bennett, E.V. Cowdry, D.W. Fawcett, D.E. Green, A.B. Novikoff, J.D. Robertson, and F.S. Sjöstrand, among others. The topic of the second one was Nucleic Acid Metabolism, Cell Differentiation and Cancer Growth, and was attended by $\mathrm{H}$. Busch, E.V. Cowdry, J.D. Ebert, P.S. Fitzgerald, S. Spiegelman, B. Thorell and others. The foundation of the Japan Society for Cellular Chemistry thus contributed immensely to the promotion of cell biology in Japan.

\section{Renaming as the Japan Society for Cell Biology (JSCB), 1964}

With the founding of the ASCB in 1960, research in cell biology developed rapidly in the United States. In 1955 the Rockefeller Institute began to publish the Journal of Biophysical and Biochemical Cytology which became the leading journal in the field, later renamed Journal of Cell Biology in 1962. These remarkable developments left a strong impression on the members of our Society.

From 1961 to 1963 Yutaka Tashiro was studying at the Rockefeller Institute's Department of Cytology chaired by George E. Palade, and could observe firsthand the birth of cell biology in the United States. It instantly made him realize that the Japan Society for Cellular Chemistry should change its name to the Japan Society for Cell Biology.

However, the plan to change the name of the society was not so realistic. More than 10 years had passed since the tentative name was agreed upon, and there was also a con- 


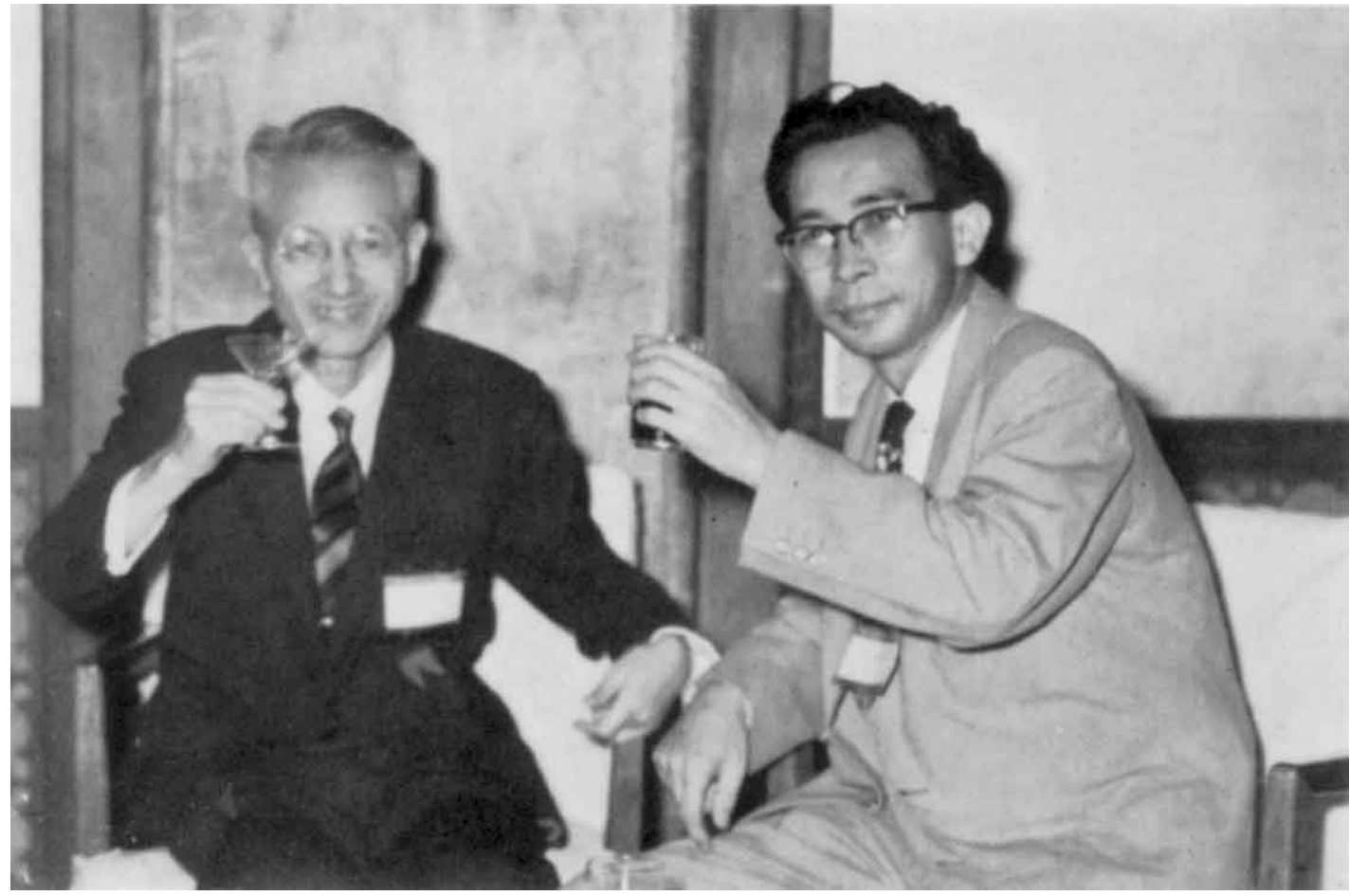

Fig. 2. Dr. Shigeyasu Amano (1903-1964) (left) and Dr. Satimaru Seno (born 1915). Two intimate colleagues of Dr. Katsunuma when he founded the Japan Society for Cellular Chemistry in 1950.

servative group of histochemists who were happy the way things were. On the other hand, there was a number of eager, young members, such as Hiroto Naora, Masaatsu Yamada, Taijo Takahashi and Yutaka Tashiro, who having studied cell biology in the United States, strongly insisted that the society be renamed immediately. They achieved this goal in 1964, thanks to the vigorous leadership of Tachio Ishikawa, then President of the 17th Symposium. He succeeded in getting the council of this symposium to agree to renaming the Society. The other author, Tohru Okigaki, a member of the ASCB and studying under Charles M. Pomerat in the U.S. at that time, was informed this news from Japan and received it with great satisfaction.

Later, in 1968, the Symposia of the Society for Cellular Chemistry was changed to Symposia of the Society for Cell Biology, and then simply to Symposium for Cell Biology (Table I).

\section{Reformation of the JSCB, 1964-1977}

While our Society was originally founded on the philosophy of Katsunuma that the Society should be open and free, there was still no Constitution for the Society. Presiders of the annual meetings served concurrently as President of the Society as shown in Table I, then Secretary General of the Society Satimaru Seno serving from the inception of the Society in 1950. Council members were appointed by the President and no voting system existed.
As the membership increased and the Society's activities escalated, there was a need to reform the Society to make it a more visible and established one. A Constitution was made in 1966 and revised in 1969.

According to the revised Constitution, the President, Executive Committee and Council Members would be determined by ballot vote. First, the Council Members with would be elected 4 year terms; their numbers would be approximately $10 \%$ that of the society members. Then the Executive Committee with 2 year term and a maximum 4 year term would be determined by the Council Members, the number of Executives being 10\% that of the Council Members. For the election of the President, the first three candidates would be determined by the Executive Committee, and then the President was finally elected by all the members. The president serves for a 2 year term and a maximum 4 year term. The first President elect was Satimaru Seno (1970-1973).

In 1974, Noburo Kamiya, the second President elect, successfully carried out extensive reformation of the Society. The major reform points were as follows:

(1) The format of the annual meeting was modified so as to incorporate general oral and poster presentations in addition to symposia.

(2) A new international journal, Cell Structure and Function (CSF), was initiated in 1975 as described below.

(3) The JSCB secretarial office was moved from Okayama University to Nakanishi Printing Co., in Kyoto 1978, so 
Table I. Chronological TABle OF THE JAPAN SOCIETY FOR CELL BIOLOGY SINCE 1950. From THE JAPAN SOCIETY FOR CELLULAR CHEMISTRY (1950-1963) TO THE JAPAN SOCIETY FOR CELL BIOLOGY (1964-). HISTORICAL LIST OF MEETING LOCATIONS, MEETING PRESIDERS, PUBLICATIONS AND PRESIDENTS 1950-2000.

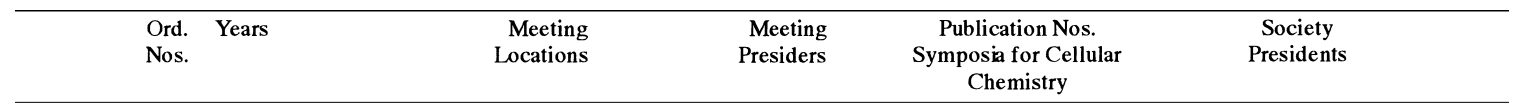

Japan Society of Cellular Chemistry (1950-1963)

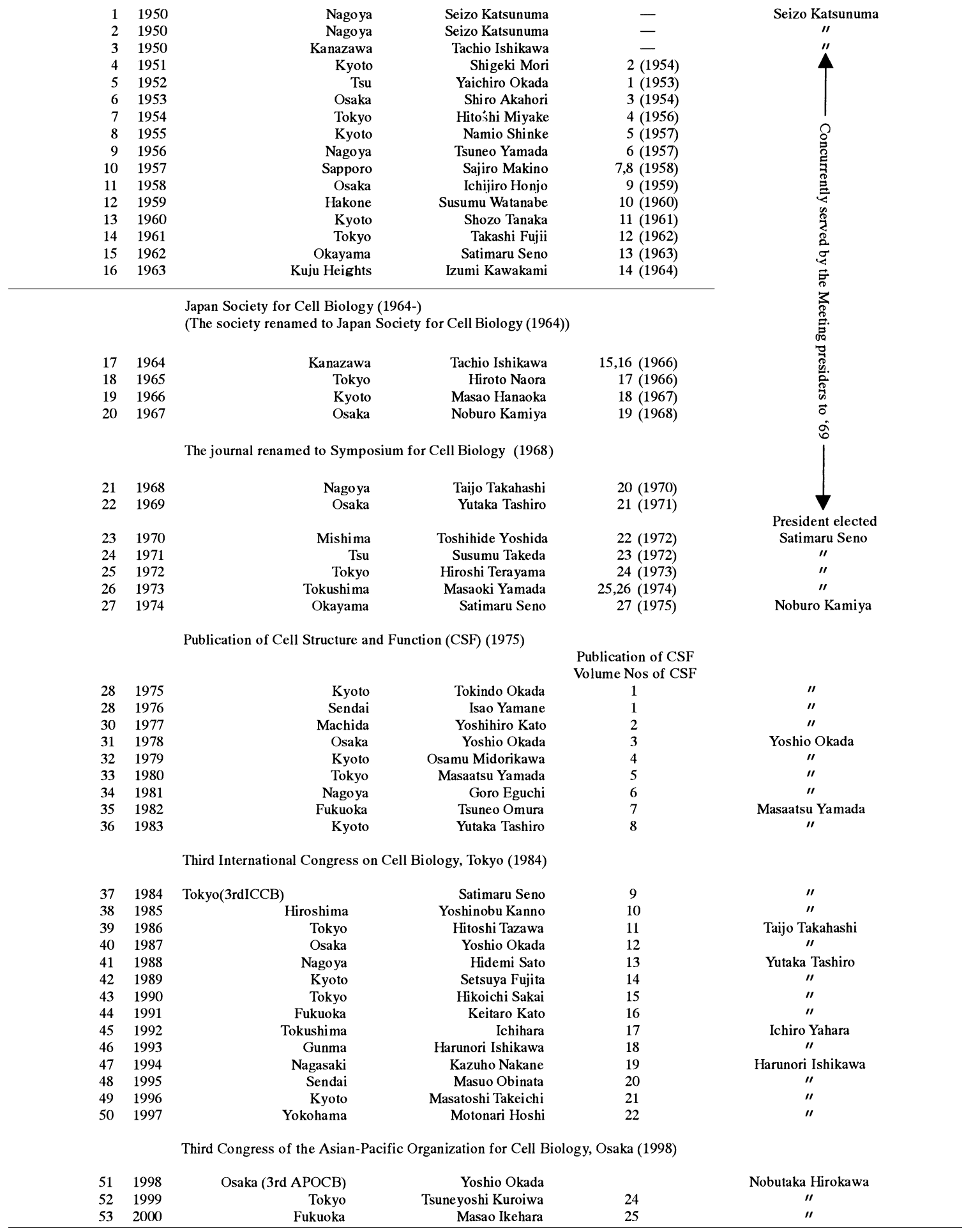


as to facilitate rapid growth of the Society. While the Society was young, it was absolutely essential to have strong founders and leaders like Seizo Katsunuma, Shigeyasu Amano and Satimaru Seno. But, as the Society became established and matured, more democratic modern management was required. Relocation of the secretarial office to Kyoto advanced the modernization of the Society.

\section{Publication of Cell Structure and Function (CSF) 1975}

As mentioned above, with the exception of a brief period at the very beginning (1950) as shown in Table I, the Society has been publishing an annual periodical initially called Symposia of the Society for Cellular Chemistry or Symposia for Cellular Chemistry, later Symposia of Japan Society for Cell Biology from 1968. These were the proceedings of the annual symposia written in Japanese with short English summaries.

In 1975, when the JSCB was allowed to become a member of Science Council of Japan, it was suggested for the Society to publish an original journal at the international level. After long and fruitful discussion, the Society ceased publication of Symposium of the Society for Cell Biology and in 1975 started a new English journal named Cell Structure and Function. The Editor-in-chief of this new journal was Satimaru Seno (1975-1978), followed by Taijo Takahashi (1979-1984), Yutaka Tashiro (1985-1988), Ichiro Yahara (1989-1992), Nobutaka Hirokawa (1993-1998) and presently Kazuhiro Nagata (1999 to date). Initially the journal had been published quarterly, but in 1987 it became bimonthly and in 1990 it was changed to international A4 size from B5.

Current total journal pages is 700 to 800 pages annually with 30 to 80 original articles, various review articles and abstracts of the annual meetings and related meetings. The total number of copies distributed within and without Japan is approximately 2,000 .

Impact factor is approximately 1.0 ranging from $0.8-1.4$ in recent years. Total annual cost needed for the publication is roughly 20 million Japanese yen which corresponds to approximately $80 \%$ of the Society's annual budget.

\section{JSCB Participation in the Science Council of Japan, 1975}

Science Council of Japan is composed of a number of societies from various fields of natural, social and humanistic sciences. In medical science, for example societies based on traditional fields like anatomy, physiology and biochemistry have been registered with the Council from the beginning. In the past, new and interdisciplinary societies like JSCB were not allowed to be registered.

Regrettably, only registered societies can participate in the distribution of research grants from the Ministry of Edu- cation and Science, thus it was very crucial for any academic society to be registered.

Owing to the strong leadership of the second President, Noburo Kamiya, the Liaison Committee for Cell Biology was allowed to be organized in the Science Council of Japan in 1975. Later, in 1985, when Hiroshi Tarayama served as a representative of the Science Council of Japan, the JSCB finally became a registered society of the Council.

\section{Acquisition of Cell Biology Section in the Grants-in-aid Program of the Ministry of Education and Science, Japan, 1993}

Currently the Ministry of Education and Science distributes approximately 150 billion yen annually for the promotion of science in the country, thus for scientists with research interests obtaining the grants from the Ministry is of crucial importance. The grants are distributed through various study sections, hence establishing a cell biology study section in the grant system is of much importance. It was no easy matter for us to acquire our own cell biology section, however, and it took more than 20 years for us to succeed.

It may be necessary to explain how study sections in medical and biological sciences are composed. Basic medical science is composed of Anatomy, Physiology, Biochemistry, Pathology, Microbiology, Parasitology, Virology, Immunology and Pharmacology. It is amazing that Cell and Molecular Biology sections did not exist. This disastrous situation of Japan is completely different from that of the United States, where molecular and cell biology has long been recognized as one of the most important research topics in the field of biological and medical sciences.

Toward this end, our society had made strenuous efforts to establish a cell biology study section beginning our campaign in 1974 and it was in 1991 when we succeded to get a provisional one for molecular and cell biology in the interdisciplinary field, which was certainly a great achievement for the JSCB. Finally in 1993, a full-fledged Cell Biology study section was established.

\section{Hosting the 3rd International Congress on Cell Biology, 1984}

In 1984, the JSCB hosted the 3rd International Congress on Cell Biology (ICCB) in Tokyo under the auspices of the International Federation of Cell Biology (IFCB). At that time there were only 750 society members and we were not confident that the society could manage such a huge international congress successfully. The IFCB was originally organized in 1976 by three cell biology research groups: the ASCB, the European Cell Biology Organization (EMBO) and the JSCB. It was founded under the leadership of the ASCB, and at the founding meeting in St. Louis in 1972, the JSCB was represented by Satimaru Seno, Tohru Okigaki and Tsuneo Yamada. 
The 3rd ICCB in 1984 was held successfully in Tokyo with a total of 2,486 participants from over 50 countries. Seno and Okigaki served as President and Secretary General of the Congress, respectively. At this Congress nearly 1,700 papers were presented and discussed. International Cell Biology 1984, which was published by the JSCB included abstracts of all the papers presented at the 3rd ICCB. In addition, Recent Progress in Cell Biology in Japan was published as a special issue for the 3rd ICCB (Cell Struct. Funct. 9, Supplement (1984)), which consisted of a collection of short reviews by Japanese researchers in the field of cell biology. This issue was published to introduce the current status of cell biology in Japan to all overseas participants of the 3rd ICCB.

It must be emphasized that at this Congress, there was a big delegation totaling 36 scientists from China headed by Zhen Yao, President of the Chinese Society for Cell Biology (CSCB). President Seno and Secretary General Okigaki believed that the JSCB should not miss this golden opportunity to establish the Asian-Pacific Organization for Cell Biology (APOCB) for the betterment of scientific interrelation among Asian colleagues. The founding meeting for the
APOCB was proposed by Seno, at which time over 30 Asian cell biologists volunteered to discuss the basis of founding the APOCB in the future. Yao, a leader of the CSCB, and Okigaki of the JSCB with diplomatic expertise played key roles in founding the APOCB.

\section{APOCB and JSCB}

The APOCB was officially founded in Montreal, Canada, in 1988 on the occasion of the 4th ICCB. At this meeting Yao was appointed as its first president and Okigaki as secretary general. In 1990, the 1st APOCB meeting was held in Shanghai, China. Along with President Tashiro and a good number of the JSCB delegation who attended also visited the Shanghai Joint Laboratory of Life Science and the Shanghai Institute of Cell Biology to exchange ideas.

In 1994 the 2nd APOCB Congress was held in Sydney, Australia presided by J. Walton. In 1998 the 3rd Congress was held in Osaka, Japan, presided by Yoshio Okada of Osaka University, while APOCB President was serviced by Yutaka Tashiro. The APOCB now consists of over 20 countries and regions in the Asian-Pacific area. The 4th Con-

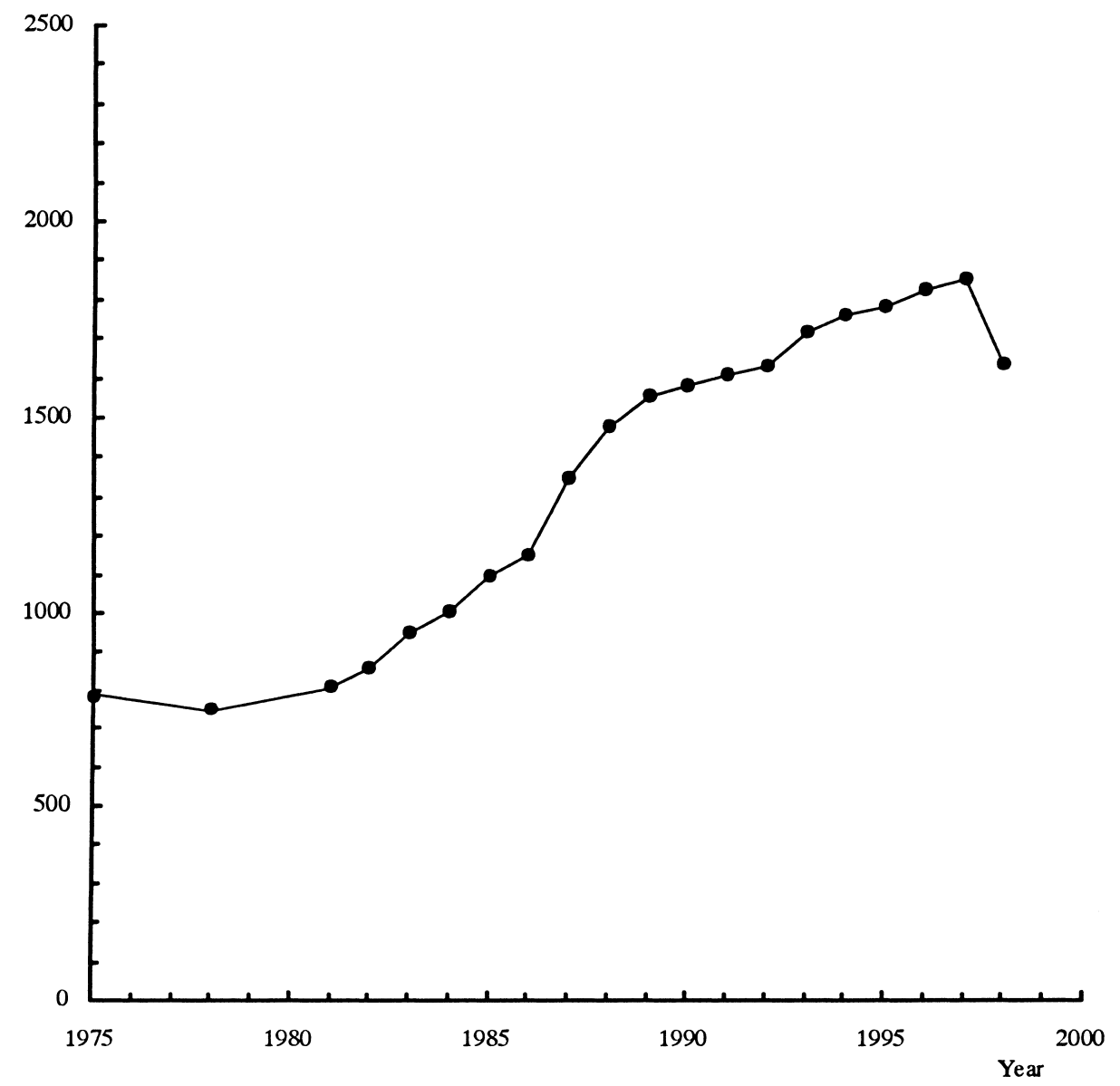

Fig. 3. Society Membership of the Japan Society for Cell Biology (1975-). 
gress will be held in Taipei, Taiwan in 2002 under President C.W. Wu.

\section{The Present State of the JSCB}

Finally, touching on the present state of the JSCB should be mentioned, Fig. 3 shows the number of Society members. In 1984 when the 3rd ICCB was held, the membership number was approximately 800 , after which it started to increase rapidly before gradually reaching some 1,800 members today. This number is less than $20 \%$ of the membership of the ASCB.

Fig. 4 shows the total number of all types of presentations at the annual meetings, including plenary lectures, symposia, workshops, and oral and poster presentations. The average annual number is 300 to 400 , which is only 10 to $20 \%$ that of the ASCB.

When our journal, the CSF, is compared with their Molecular Cell Biology (MCB), the situation is quite similar, the total pages and Impact Factor of our CSF being only one tenth those of the MCB.
Since the population of Japan is almost $50 \%$ that of the United States, the present state of the JSCB is far less than that one might expect. There are several reasons for this.

1) The pioneers who founded the ASCB were primarily electron microscopists such as K. Porter, G.E. Palade, H.S. Bennett and D.W. Fawcett, who realized that active collaboration with biochemists and physiologists even physicists was needed to create a new interdisciplinary field called cell biology. They even reformed themselves to become cell biologists. Most of the anatomy laboratories in U.S. universities and colleges renamed themselves to become Departments of Cell Biology or Cell Biology and Anatomy, in which they have been playing an active role as research centers in the field of biomedical sciences especially emphasizing molecular and cell biology.

In Japan, a number of outstanding electron microscopists like E. Yamada and K. Hama have been recognized internationally, although most of them had stayed in electron microscopy. Recently, however, the Departments of Anatomy chaired by H. Ishikawa of Gumma University, N. Hirokawa of University of Tokyo, and Y. Yoneda of Osaka Universi-

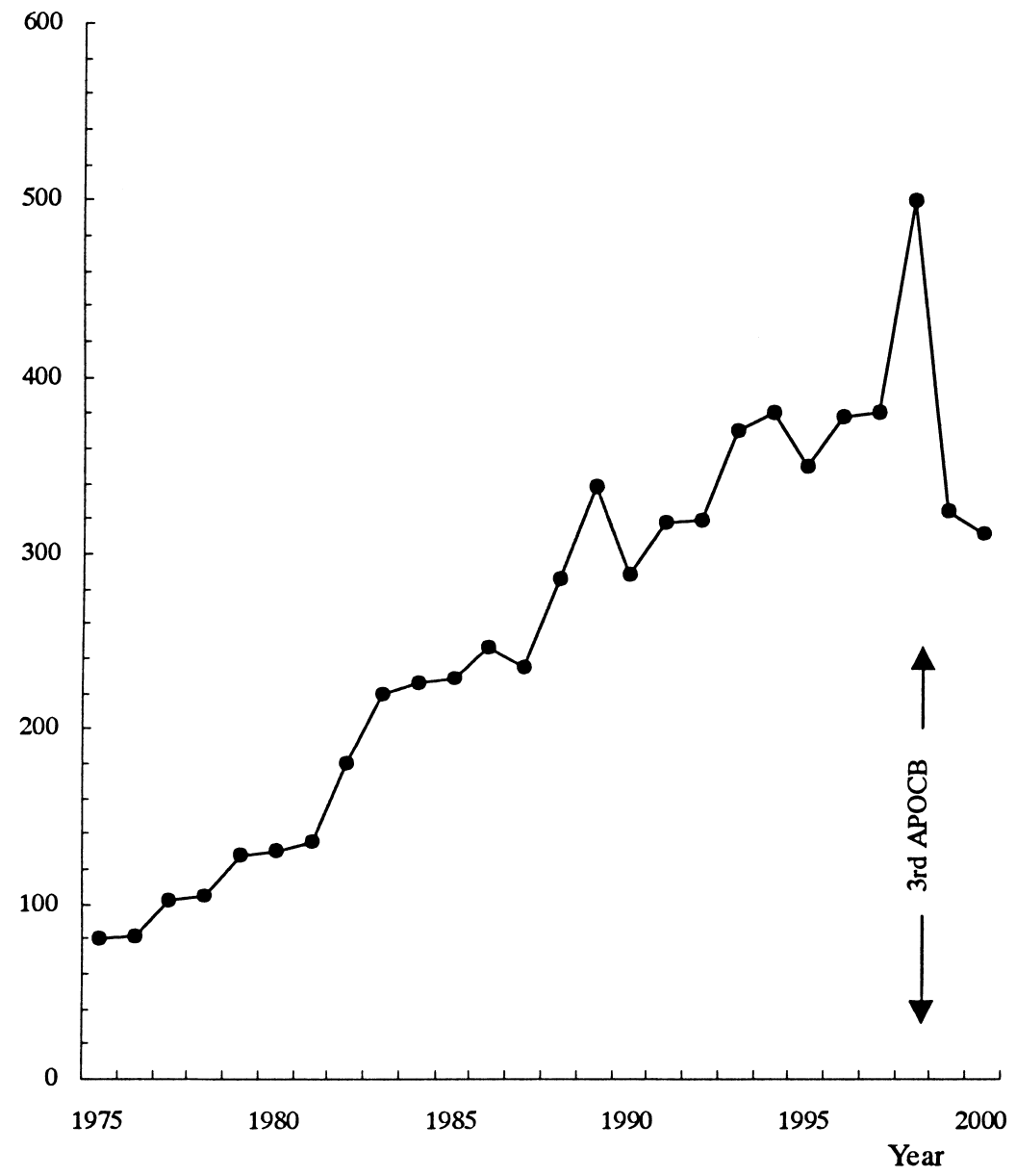

Fig. 4. Total number of presentations at the annual meeting of the Japan Society for Cell Biology (1975-2000). 
ty, among others, have been transformed to Departments of Anatomy and Cell Biology. In other words, the promotion of cell biology is taking place in Japan, even though it certainly took time.

2) As explained previously, it was initially difficult for cell biologists to obtain research grants from the Ministry of Education and Science of Japan. This hectic situation is much improved, as described above.

3 ) In addition to the JSCB, there are several other closelyrelated research-oriented societies in biochemistry, molecular biology and developmental biology. In the U.S., biochemistry and molecular biology are unified, and developmental biology was merged to cell biology. Such rationalized unification of the academic fields in Japan is somewhat problematic.

In conclusion, the authors wish to point out that the JSCB has been blazing a path for the promotion of life science in Japan by establishing cell biology as you find in the present article. It is also our wish that junior cell biologists will wisely choose to contribute their worthwhile works internationally.

This historical article limited its account to the history of the Society itself, with the history of scientific contributions made by individual Japanese cell biologists has not been included in this article. We hope that a historical account of the various fields of cell biology as pursued in Japan will one day be introduced in a future issue of this journal.

Acknowledgments. We are grateful to Satimaru Seno, one of the founders of the JSCB, for kindly reading this manuscript and giving us his advice. We also thank N. Kurokawa and Y. Miyashita of Kansai Medical University and N. Nishimoto of Shigei Medical Research Institute, for their time consuming work of manuscript preparation. 